\title{
Non-Hemolytic Streptococcus
}

National Cancer Institute

\section{Source}

National Cancer Institute. Non-Hemolytic Streptococcus. NCI Thesaurus. Code C123553.

A bacterium that is assigned to the genus Streptococcus that is unable to facilitate red blood cell lysis. 